Душан Р. ЖИВКОВИЋ

Универзитет у Крагујевцу Филолошко-уметнички факултет
Оригинални научни рад

Примљен: 07. 10. 2019.

Прихваћен: 12. 02. 2020.

\title{
УТИЦАЈ ХЕРМЕТИЗМА НА ЕНЦИКЛОПЕДИЈСКУ ПАРАДИГМУ ХАЗАРСКОГ РЕЧНИКА ${ }^{* *}$
}

\begin{abstract}
У раду се анализира утицај херметизма на енциклопедијску парадигму Хазарског речника Милорада Павића, посредством следећих аспеката: а) аутопоетичких ставова; б) креирања и умрежавања речничких одредница; в) семантичких карактеристика, остварених у полифонији, дифузности, синхроницитету и амбигвитетима романескне фикције.

Павићева енциклопедијска парадигма оживљава култ Хермеса Трисмегистоса, призивајући његово божанско порекло изумитеља писања, енциклопедијских система, као и преносника информација - отелотворења принципа интерконтекстуалности. Такође, Павић надграђује херметичке принципе, креирајући хипертекст - интерактивни систем умножавања значења, у вишеслојним дијалозима са читаоцима као сарадницима у стварању постмодерног херметичког лавиринта.

У херметичким учењима, три је број андрогина, а у теозофској примени херметизма постоји идеја о прожимању религија која је имала кључни утицај на речничку концепцију тројства у јединству „Црвене”, „Зелене” и „Жуте” књиге (хришћанских, исламских и јеврејских извора), као и у мисији обједињавања мушког и женског примерка - у састављању Адамовог андрогиног тела на земљи и сабирању свих просторно-временских перспектива у универзално - свевидеће време Хазарског речника.

Кључне речи: Милорад Павић, Хазарски речник, енциклопедијска парадигма, херметизам, теозофија, постмодернизам, хипертекст.
\end{abstract}

Павић је у Хазарском речнику (1984) остварио иновације у светској књижевности, од поетичких до семантичких елемената (уп. Јерков 1992: 211), пошто је применио, осавременио и проширио Екову теорију отвореног дела (уп. Делић 1991: 264) на форму речника, ${ }^{1}$ створивши, како истичу Јасмина Михајловић $^{2}$ и Сава Дамјанов, ${ }^{3}$ прво хипертекстуално дело природно ство-

*dusan.zivkovic@filum.kg.ac.rs

** Рад је део истраживања на пројекту 178018 Друштвене кризе и савремена српска књиюевност и култура: национални, регионални, европски и глобални оквир Министарства просвете, науке и технолошког развоја Републике Србије.

${ }^{1}$ Такође, Никола Милошевић истиче да „Павићево отворено дело сеже до граница оног што се зове трансцендентно" (http://www.rastko.rs/knjizevnost/pavic/knjiz_portret/05_pkp_milosevic_c.html).

${ }^{2}$ http://www.khazars.com/pavic-i-hiperbeletristika.

${ }^{3} \mathrm{http}: / /$ www.rastko.rs/cms/files/books/4d38bf7fc5fbc 
рено за интерактивно окружење у споју информатичких принципа и древног херметичког поимања мреже текстова. ${ }^{4}$ „Тако је Павић остварио енциклопедијску мисију следбеника Хермеса Трисмегистоса, створивши системски хипертекст” (Живковић 2019а: 118).

Наш научни допринос у овом раду састоји се у обједињавању општих и посебних елемената херметизма у Хазарском речнику, од анализе интертекстуалних веза са изворним херметичким списима, до многоструких историјских и савремених тумачења херметичких тајни, у циљу расветљавања њихове улоге у Павићевим надградњама и иновацијама енциклопедијске парадигме: од структуралних, преко идејних до тематских аспеката. Такође, да бисмо разумели природу и фунције Павићевих иновација, неопходно је да се вратимо извору херметизма и његовом значају у историји цивилизације.

Извор херметизма представља мистичну египатско-грчку традицију

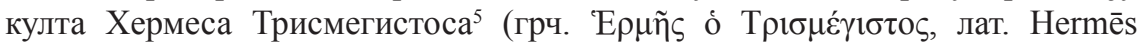

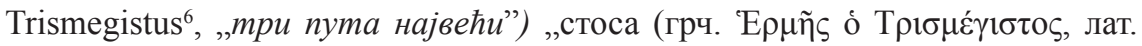
Hermēs Trismegistus ${ }^{7}$, „mpu nyma највећu”) - као споја египатског бога Тота (Thoth), бога знања, мудрости, библиотеке и енциклопедијске парадигме, „креатора језика, тумача и саветника богова”, ,„изумитеља писања и заштитника свих уметности и вештина (arts) зависних од писања") и грчког бога Хермеса (гласника богова, бога информација, двосмислености (уп. Еко 2001) - као оваплоћења принципа интерконтекстуалности. Херметизам је обликовао енциклопедијску парадигму Хазарског речника, у поимању умрежености кодова, амбигвитета и плурализма, по узору на принцип функционисања основног херметичког „тела” текстова - Corpus Hermeticum-a, чиме ce, у дифузним дијалозима, успоставља отелотворење хермесовског присуства на два или више места истовремено.

Под утицајем херметизма - принцип Ars Combinatoria (уп. Мигуел 2008: $115-116$, уп. Лајбниц 1666), ${ }^{10}$ може се применити и на отвореност ${ }^{11}$ игре комбинаторичких могућности стварања и тумачења постмодерног књижевног

4 „Да би успоставио Logos међу мистериозним подацима, др Абу Кабир Муавија, један од кључних јунака у потрази за истинама о Хазарима у 20. веку, одлучује се за интелигенцију компјутера, док процесе уношења података, као и исхода њихове повезаности, објашњава посредством херметичких аспеката вишеслојности, амбигвитета, интерференције и дифузности" (Живковић 2016: 146).

${ }^{5}$ На, пример, Три иницијата - аутори Kybalion-a, 1908) користе латински средњовековни назив Hermes Trismegis'tus.

${ }^{6}$ https://www.thefreedictionary.com/Hermes+Trismegistos. Такође, назив Mercurius Ter Maximus упућује на виђење Хермеса Трисмегистоса у римској митологији (уп. Баез 2012).

${ }^{7} \mathrm{https}$ ://www.thefreedictionary.com/Hermes+Trismegistos.

${ }^{8} \mathrm{https}$ ://www.britannica.com/topic/Thoth.

${ }^{9} \mathrm{https}$ ://www.britannica.com/topic/Hermetic-writings.

${ }^{10}$ Готфрид Вилхелм Лајбниц (Gottfried Wilhelm Leibniz, 1646-1716) дефинисао је принцип Ars Combinatoria у студији Dissertatio de arte combinatoria (1666) која му је била подстрек на путу ка обликовању бинарног система, као основе рада компјутера.

${ }^{11}$ Привидно контардикторно делују блискости између теорије отвореног дела и све раширенија колоквијална употреба атрибута „херметички” (у смислу затвореног мистичног система), а заправо у студији Отворено дело, као и у Границама тумачења Еко наводи да треба створити активног ерудитног, посвећеног читаоца, кога би писац заправо иницирао на путу сазнања, створивши креативног саговорника и коаутора у стварању универзума значења. 
дела $^{12}$ коју одређује принцип укрштаја у сагласју са мистичним елементима. Тако мистика и наука директно делују на поетику и семантички систем дела, у многострукости комбинација знакова и значења, у свести да је хипертекст заправо слика и последица бескрајног укрштаја знакова.

Вођен изворном херметичком традицијом, (која напаја својом енергијом древне и савремене мислиоце), као и путоказом постмодерне поетике и у ужем смислу - елемената хипертекста у Борхесовом стваралаштву, ${ }^{13}$ Павић је један од утемељивача ере умрежености савременог човека у интерактивном свету - у лавиринту који постаје стварнији од саме физичке појавности ван интернета" (уп. Живковић 2019а: 119).

Посредством интерактивне књижевности (compunovels, nonlinear narratives) стварају се нове технике писања (уп. Кувер 1993: 7) које су отвориле и могућности креирања различитих токова читања. „Ту је процес све, нема фиксног производа или текста, постоји само активност читаоца, и као произвођача и као примаоца" (Хачион 1996: 138). У овим процесима, интерактивна књижевност постаје доминантни вид постмодернистичке уметности, чиме заправо древни херметички принципи динамичности дијалога са читаоцем добијају ново технолошко оваплоћење. Универзум херметизма представља отелотворење принципа умрежавања текстова, сагласја, нелинеарности, симултаности, синхроницитета (уп. Хамваш 2012: 159), реверзибилности, дифузности и генерално - динамичности контекста (херметички принцип вибрације: „Све је у покрету” (Три иницијата 1908: 10).

Херметичка свест о о мрежи текстова представљена је кроз топос лавиринта, у коме је отелотворена аналогија између структуре Павићеве енциклопедијске парадигме и херметичких елемената у архитектури.

Наиме, Самуел Коен (1660-1689), један од састављача Хазарског речни$к а$ (по изгнанству из Дубровника), живи у Београду, у „старом хану у једној од 47 одаја" (Павић 2004: 299) а управо 47 одредница (рачунајући и два апендикса) садржи Павићев Хазарски речник; метафорично речено - свака одаја одговара једној одредници, ходници представљају заправо њихове тајне интертекстуалне везе, а степеништа - нове нивое сазнања. ${ }^{14}$

Такође, аналогије са мистичним принципима архитектуре уграђене су у саму основу херметизма, пошто постоји веровање да је Тот (египатско лице и извор култа Хермеса Трисмегистоса) заправо и велики архитекта пирамида (уп. Три иницијата 1908: 14). Поред ових општих паралела, карактеристи-

12 У есеју Постомдернизација фантастике код Павића, Сава Дамјанов је дао допринос у проучавању односа комбинаторичких принципа и нелинеарности постмодернистичке уметности (https://www.rastko.rs/knjizevnost/pavic/knjiz_portret/09_pkp_damjanov.html).

${ }^{13}$ Хорхе Луис Борхес (Jorge Luis Borges, 1899-1986) објавио је 1941. године кратку причу Bрm са стазама које се рачвајy (The Garden of Forking Paths), која је постала основа будућих система хипертекста.

${ }^{14}$ https://awakenedonez.files.wordpress.com/2018/11/the-emerald-tablets.pdf.

Наведене мистичне аналогије евидентне су и у Павићевом роману Унутрашња страна веmpa (1991), у којима се сугеришу мнемотехнички принципи, по којима се сугерише ученицима да у циљу бољег памћења градива замисле да један сегмент текста одговара једној просторији у грађевини сложене структуре, што представља аргумент да Павићево стваралаштво треба посматрати у тоталитету значења, са Хазарским речником као поетичком и семантичком основом. 
чна је специфичност трагања за тајном (као кључем спознаје) која се крије у лавиринту пирамиде. У Смарагдним таблицама (The Emerald Tablets) Тот, језиком загонетки (Смарагдна таблица, 5) саветује своје следбенике како да пронађу кључ спознаје: „Претражи и пронађи у пирамиди коју сам саградио. Прати кључ који остављам иза себе. Тражи и врата за живот ће бити твоја. Потражи моју пирамиду дубоко у пролазу који се завршава у зиду". ${ }^{15}$

У Хазарском речнику је наговештен наведени процес трагања за сазнањем у лавиринту грађевине: „Коеново лутање обележено је непрестаном метаморфозом простора и времена: ${ }^{16}$ ходник се претвара у зид, док се степенасти зид преображава у употребљиво степениште, остајући и даље исти као и до тада, само што се светлост која се раније пред Коеном видела у дну ходника сада налази високо изнад њега" (Живковић 2016: 136).

У структурирању 47 одредница присутна је и интерференција херметичких принципа и мита о састављању Адамовог тела, управо у просторно-временским метафорама: „Хазари будућност замишљају у простору, а никада у времену” (Павић 2004: 163). Наведени реверзибилни просторно-временски односи означавају отелотворење и преплитање Адамове и Хермесове суштине, у коме тело - као просторна одредница, обухвата заправо све временске перспективе, тежећи да се оствари у универзалном времену (уп. Живковић 2019б: 60-61).

У овој мисији остварена је интерференција херметизма, кабалистичких (уп. Халамиш 1999) и теозофских схватања (уп. Блавацка 2006) у фигурацији Адама Кадмона - „човека пре пада, целовитог, андрогиног и безгрешног” (Пауновић 2012: 48) - у симболици бројева и слова, као и поетици белина - размака између земаљских слова у којима је скривена суштина небеског писма. Дакле, поред преплитања елемената херметизма (египатско-грчке традиције) и Кабале (јеврејске традиције), у Хазарском речннику евидентан је и новији, деветнаестовековни слој обједињавања мистичних знања - оличен у теозофији, која је, прилагођена интелектуалцима космополитског духа, на Павића утицала кроз модификовано виђење Адама Кадмона, у обједињавању древних знања Истока и Запада. ${ }^{17}$

Наведене мистичне везе имају и своју нумеролошку основу. У херметичким учењима, један је мушки број, два је женски број, а три је број андрогина. ${ }^{18}$ Управо повезивање и обједињавање значења све три књиге Хазарског речника означава пут ка састављању Адамовог андрогиног тела. „Трећи је трансуматни облик јединства. Центроверзија, То је андрогин” (Хамваш 2012: 200).

\footnotetext{
${ }^{15}$ https://awakenedonez.files.wordpress.com/2018/11/theemerald-tablets.pdf. Сви цитати из литературе на енглеском језику дати су у преводу аутора рада, за потребе овог истраживања.

16 Динамичност промене простора и времена у Хазарском речнику упућује и на обележје Хермеса Трисмегистоса као заштитника путника.

${ }^{17}$ О утицају теозофског тумачења херметизма сведочи доминација утицаја Г. Р. С. Мида (G.R.S. Mead), (једног од најутицајнијих теозофа) у тумачењу Corpus Hermeticum-a - основног система херметичких текстова.

18 „Сваком сложеном телу придодат је број, јер без броја не би могла постојати структура ни густина. Без броја се структура не би могла ни саставити ни раставити. Једиство је то што даје рођење броју и увећава га, а растављањем их поново враћа себи” (Трисмегистос 2018: 411).
} 
Ове херметичке нумеролошке законитости допуњене су утицајем теозофских модификација у Хазарском речику - у основној идеји: све религије се прожимају ${ }^{19}$ и чине јединство, једна другу допуњују, да би саставиле целину Хазарског речника. Дакле, примене херметичких принципа у теозофским учењима, ${ }^{20}$ утицале су на концепте спајања „Жуте”, „Црвене” и „Зелене књиге" - јеврејских, хришћанских и исламских канонских и неканонских извора Хазарског речника: у обједињавању различитих виђења божанске мудрости, посредством упоређивања њихових сличности и специфичности, сједињењем у заједничком језгру религија (уп. Блавацка 2006) - у стварању Књиге-Логоса (уп. Живковић 2019б: 69) - Тројства у јединству.

Такође, у анализи фигурације андрогина у Хазарском речнику треба споменути и херметичке димензије алхемије, објашњење у картама Тарота које објашњава Бела Хамваш у херметичком спису Табула Смарагдина. ${ }^{21}$ „СамехСатурн у знаку живе (коагулације). Спајање треба да буде у знаку андрогина. Ко нађе ову операцију иступио је из круга ђавола. Алхемија каже да је то реализација Ле^ли. У новије време се божанска операција у знаку андрогина назива theandria (Соловјев)" (Хамваш 2012: 311).

Састављање андрогина остварује се помоћу обједињавања мушког и женског примерка Хазарског речника. „Тако је заправо створена идеја „апсолутног" интертекста: текст се тако састоји у спајању полова књиге, ${ }^{22}$ пошто је хазарска принцеза Атех саставила женски део хазарске енциклопедије, а њен љубавник, Мокадаса Ал Сафер, састављач је мушког примерка. У мисији састављања Хазарског речника, од средњег века до савременог доба, љубавна енергија Атех и Мокадасе повезује све будуће коауторе и настављаче" (Живковић 2019б: 64).

Такође, Мид објашњава спајање мушког и женског принципа: „То је Он који је стајао, који стоји и који ће стајати, мушко-женска моћ, као препостојећа бескрајна Моћ која нема ни почетка ни краја, која постоји у јединству” (Мид 2018: 377). Ова херметичка тајна у Мидовим теозофским тумачењима херметизма аналогна је са Павићевим аутопоетичким ставом о бескрајним

19 У мисији састављања тела Адама Кадмона, богумилски сегменти учења Аврама Бранковића (уп. Радуловић 2012: 437) преплићу се у ониричком свету са кабалистичким принципима његовог двојника Самуела Коена, а овакав начин спајања разнороднх принципа иманентан је основи теозофских схватања о упоредним проучавањима и прожимањима езотеријских учења разнородних религија (https://www.britannica.com/topic/theosophy).

${ }^{20}$ „Основни циљеви Теозофског друштва изражени су у тзв. три објекта: да формира језгро универзалног братства човечанства, без разлике у раси, вероисповести, полу, касти или боји; да подстакне проучавање компаративне религије, филозофије и науке; и да истражи необјашњене законе природе и силе скривене у људским бићима” (https://www.britannica.com/topic/ theosophy).

21 У студији Иницијација у херметизам, Франц Бардон објашњава узвишени, мистични смисао тарота: „Већина читалаца ће, наравно, знат, да реч 'ТАРОТ' не означава карте за играње, које служе у мантичке (прорицаљске) сврхе, него симболичку књигу иницијације која садржи највеће тајне у облику симбола.” (3http://www.4shared.com/get/wXUvJaZd/Bardon_Franc__Inicijacija_ u_html). Такође, док је симболика тарота наговештена у Хазарском речнику, у Павићевом роману Последња љубав у Цариграду (1994) има доминантну поетичку и семантичку улогу.

${ }^{22}$ Принцип пола садржан је у самој основи херметичких учења: „VII. Принцип пола. „Пол је у свему; све има своје мушко и женско начело. Пол се манифестује на свим нивоима” (Три иницијата 1908: 12). 
значењима романа, у форми реторског питања: „Мора ли роман имати крај? И шта је заправо завршетак једног романа, једног књижевног дела? (...) Стога, моји романи не познају завршетак у оном класичном значењу те речи."23

Након анализе односа мушког и женског и принципа, значајну улогу имају и двојности у повезаним судбинама мушких ликова Хазарског речника, на различитим меридијанима, јер „Два раздваја простор и време” (Хамваш 2012: 213). Наиме, Хамваш истиче да постоји „позитивно два” (2012: 311) принцип креативног дјалога, а да је негативно два - ђавоље дело и да „Треба одбацити сваког демона.” (2012: 311) (...) „Негативно два је анатема” (Хамваш 2012: 214). Ова нумеролошка законитост се може применити на однос нечистих сила према мисији састављања Хазарског речника: демони јеврејског, хришћанског и исламског света желе да спрече стварање енциклопедијске парадигме која би означавала састављање Адановог тела на земљи. Демони желе да створе негативно два, односно да састављачи никада заиста не успоставе креативни дијалог на јави, пошто Аврам Бранковић (1651$1689)$ сања јаву Самуела Коена (1660-1689) и обојица бивају уништени од стране деструктивних сила. Такође, Севаст Никон, демон хришћанског света, уништава спознају мудрости хазарских тајни у трагањима Теоктиста Никољског.

С друге стране, да би читалац, као будући настављач Хазарског речника, надмудрио нечисте силе, мора, метафорично речено, спознати херметичку тајну постојања на два или више места истовремено, односно - мора остварити принципе синхроницитета и амбигвитета, у тежњи ка идеалу „критичког узорног читаоца" (Еко 2001: 29) који би заправо спознао природу Хермеса Трисмегистоса. Другим речима, читалац треба сва времена Хазарског речни$\kappa a$ да споји у универзално време, у вечну садашњост, да сва значења из свих временских слојева (уп. Марчетић 2009: 112), истовремено представи свом уму. На тај начин, читалац би постао видовит и спознао вечност, у којој не постоји прошлост и будућност, већ само садашњост: „Помисли да си одједном свугде, у земљи, у мору, на небу. Замисли да још ниси рођен, да си у материци, да си млад, да си стар, да си мртав, као и стање после смрти. И ако сазнаш све те ствари одједном - све заједно, истовремено, сва места, деловања, својства, величине, и све то одједном обухватиш својим мишљењем, тада ћеш спознати Бога" (Трисмегистос 2018: 391). Када се део ове (Десете) херметичке беседе ( $У_{м}$ Хермесу) примени на структурирање енциклопедијске парадигме Хазарског речника, теоријским језиком речено - задатак Узорног читаоца представља истовременост спознаје свих комбинација значења, као и креирање, не само нових путева читања него и нових одредница којима би се Хазарски речник даље проширивао: „Све ствари, све просторе и сва времена у себи треба остварити истовремено. Ако је то остварено или знано, а не само замишљено, тада човек постаје зналац Бога, гностик" (Мид 2018: 400). Дакле, књига је Бог (уп. Живковић 2010: 237; Живковић 2016: 395), а читалац, вођен херметичким путоказима, треба истовремено да спозна све

\footnotetext{
${ }^{23}$ 〈http://www.khazars.com/sr-YU/biografija-milorad-pavic/pocetak-i-kraj-romana.».
} 
временске слојеве који се преплићу у нелинеарној, дифузној енциклопедијској парадигми романа, да би даље, постао коаутор у њиховој међузависности, трансформацији и надградњи.

Састављачи Хазарског речника су делови великог херметичког промисла, тајне и утицајне димензије у историји цивилизације. Да би сачували своју делатност од деструктивних сила, учењаци од египатске традиције до савременог доба врше импрегнацију божанског духа у Хермесову статуу, обликујућу култ Хермеса Трисмегистоса, као дифузни систем религијске, митске, научне (уп. Дљасин 2007: 27), филозофске, уметничке и цивилизацијске спознаје уопште (уп. Фохт 1976: 183).

На основу анализе претходних аспеката, закључујемо да у доминацији теозофских примена херметизма - „списатељи, настављачи и дописивачи” (Павић 2004: 22) Хазарског речника морају спознати и изворе религија којима не припадају, спојити канонске и неканонске изворе, затим успоставити њихове дијалоге (уп. Јаус 2014: 61); даље, на следећем степену сазнања треба да постоји свест о допуњавању религија и коначно - у обједињеном виду, круна овог процеса је идеја да сама књига представља јединство религија, у универзалном, свевидећем времену, које би сабрало све просторно-временске димензије. Састављачи Хазарског речника постају у ширем смислу и сарадници у умрежавању и умножавању утицаја Корпуса херметичких текстова, јер Павићева надградња Екове теорије отвореног дела, у облику романа-лексикона, представља савремени део те велике мисије, којом се преноси вечно живи огањ - ,јединство у мноштву” (Хамваш 2012: 196) херметичких мудрости.

\section{ИЗВОРИ}

Бopxec 2006: H. L. Borhes, Maštarije, Beograd: Paideia.

Павић 2004: M. Pavić, Hazarski rečnik, „Roman-leksikon u 100.000 reči, ženski primerak", Sabrani romani Milorada Pavića, Beograd: Dereta.

\section{ЛИТЕРАТУРА}

Дамјанов 2012: С. Дамјанов, Шта то беше српска постмодерна, Београд: Књижевни гласник. Damjanov.

Дљасин 2007: Г. Дљасин, Азбука Хермеса Трисмегистоса (или молекуларни тајнопис мишьења), Београд: Zepter Book World.

Живковић 2007: Д. Живковић, Отворено дело и хипертекст, Крагујевац: $\mathrm{Ha-}$ слеђе, 8, Крагујевац, 25-32.

Живковић 2010: Типолошко поређење романа Милорада Павића и Умберта Ека и поетички и семантички аспекти интертекстуалности у романима Име руже и Хазарски речник”, докторска дисертација одбрањена на Филолошком факултету Универтитета у Београду 31.1.2011. године, Београд: Филолошки факултет. 
Живковић 2016: Д. Живковић, Отворени лавиринти: Еко и Павић, Крагујевац: ФИЛУМ.

Живковић 2019а: Д. Живковић, Херметизам и хипертекст, Крагујевац: $H a$ слеђе, 42, Крагујевац, 107-124.

Живковић 2019б: Састављање Адамовог тела на земљи у Џојсовом Уликсу и Павићевом Хазарском речнику, Крагујевац: Наслеђе, 43, Крагујевац, $57-72$.

Jayc 2014: Х. Р. Јаус, Разговор религија или: The Last Things Before The Last, Нови Сад: Летопис Матице српске, Нови Сад, 494, св. 1 и 2, 61-94.

Радуловић 2012: Н. Радуловић, Између игре и иницијације. Павић и наслеђе европског езотеризма. Нови Сад: Зборник Матице српске за књижевност и језик, Нови Сад, 60, 3, 437-459.

Baez 2012: J. M. Báez, The Verbum of Hermes (Mercurius Ter Maximus), Bloomington: Palibrio.

Bardon, F. Incijacija u hermetizam. 〈http:/www.4shared.com/get/wXUvJaZd/ Bardon Franc - Inicijacija u .html 15. 8. 2013.

Blavacka 2006: H. P. Blavacka, Tajna doktrina: sinteza nauke, religije i filozofije. Tom 1, Kosmogeneza, Beograd: Metaphysica

Damjanov, S. Pavićev lavirint. 〈http:/www.rastko.rs/cms/files/books/4d38bf7fc5fbc.> 25.7.2018.

Damjanov S. Postmodernizacija fantastike kod Pavića. 〈http://www. rastko.rs/ knjizevnost/pavic/knjiz_portret/09_pkp_damjanov. html, 11. 8. 2014.

Delić 1991: J. Delić, Hazarska prizma: tumačenje proze Milorada Pavića, Beograd, Gornji Milanovac: Prosveta, Oktoih, Dečije novine.

Ebeling 2007: F. Ebeling, The Secret History of Hermes Trismegistus: hermeticism from ancient to modern times, London: Cornell University Press.

Eko 1965: U. Eko, Otvoreno djelo, Sarajevo: Veselin Masleša.

Eco, U. Vegetal and mineral memory (The future of books). 〈http://www.bibalex. org/attachments_en/publications/files/umberto_eco_.pdf>.6. 12. 2014.

Eko 2001: U. Eko, Granice tumačenja, Beograd: Paideia.

Jerkov 1992: A. Jerkov, Nova tekstualnost: ogledi o srpskoj prozi postmodernog doba, Podgorica: Oktoih; Nikšić: Unireks.

Jung 2017: K. G. Jung, Čovek i njegovi simboli, Beograd - Podgorica: Kosmos izdavaštvo - Nova knjiga.

Kadmon, Adam. Jewish Virtual library. 〈https://www.jewishvirtuallibrary.org/ adam-kadmon. 22.2.2019.>

Kassel, C. Androgynous Man in Myth and Tradition. https://opensiuc.lib.siu.edu/ cgi/viewcontent.cgi? article $=1794 \&$ context $=$ ocj. 1.3.2019.

Kuver 1993: R. Coover, Hyperfiction: Novels for Computer, New York: The New York Times Book Review, August 29, 1993: 1-12.

Lit 2004: Leonora Leet, The Universal Kabbalah, Rochester: Inner Tratitions.

Mid 2018: G. R. S. Mid, Komentari, u: Хермес Трисмегистос, Korpus Hermetikum, Beograd: Metaphysica.

Lajbnic 1666: G. W. Leibniz, Dissertatio de arte combinatoria, Leipzig. 
Marčetić 2009: A. Marčetić, Istorija i priča, Beograd: Zavod za udžbenike.

Miguel 2008: B. O. de Miguel, Some Hermetic Aspects of Leibniz's Mathematical Rationalism, in: Marcelo Dascal (ed.), Leibniz: What Kind of Rationalist? Tel Aviv: Tel Aviv University, 111-124.

Mihajlović, J. Pavić i hiperbeletristika. 〈http://www.khazars.com/pavic-i-hiperbeletristika.> 4.8.2010.

Mihajlović, J. Priča o duši i telu: slojevi i značenja u prozi Milorada Pavića. 〈http:// www.rastko.rs/knjizevnost/pavic/jmihajlovic-dusa_telo.html. > 11.2. 2019

Milošević, N. Pavićevo otvoreno delo. 〈http://www.rastko.rs/knjizevnost/pavic/ knjiz_portret/05_pkp_milosevic_c.html. > 4.2.2019.

Pavić, M. Početak i kraj romana. 〈http://www.khazars.com/sr-YU/biografija-milorad-pavic/pocetak-i-kraj-romana.> 1. 3. 2019.

Pantić, M. Pripitomljavanje đavola. 〈http://www.rastko.rs/knjizevnost/pavic/ knjiz portret/07 pkp pantic.html.> 4.2.2019.

Paunović 2012: Z. Paunović, Komentari, u: Dž. Džojs, Uliks, Beograd: Geopoetika.

Sefer ha-zohar. Encyclopaedia Britannica. 〈http://www.britannica.com/topic/ Sefer-ha-zohar. > 1.3.2019.

Tri inicijata 1908: Three Initiates, The Kybalion: a study of the hermetic philosophy of ancient Egypt and Greece, Chicago, Illinois: The Yogi publication society, Masonic Temple.

Trismegistos 2018: H. Trismegistos, Korpus Hermetikum, Beograd: Metaphysica.

Trismegistos, Hermes. The Free Dictionary. 〈https://www.thefreedictionary.com/ Hermes+Trismegistos〉. 15.8.2018.

Theosophy. Encyclopaedia Britannica. 〈https:/www.britannica.com/topic/theosophy>. 22.2.2019.

Thoth. Encyclopaedia Britannica. 〈https://www.britannica.com/topic/Thoth.〉 13.8.2018.

Thoth. The Emerald Tablets of Thoth the Athlantean. 〈https://awakenedonez.files. wordpress.com/2018/11/the-emerald-tablets.pdf〉. 29.9.2019.

Foht 1976: I. Foht, Tajna umjetnosti, Zagreb: Školska knjiga.

Halamiš 1999: M. Halamish, An Introduction to the Kabbalah, New York: State University of New York Press.

Hamvaš 2012: B. Hamvaš, Pet genija; Tabula smaragdina, Beograd: Službeni glasnik.

Hačion 1996: L. Hačion, Poetika postmodernizma, Novi Sad: Svetovi.

Hermetic writings. ENCYCLOPAEDIA BRITANNICA. https://www.britannica. com/topic/Hermetic-writings>. 13.8.2018.

Hermetism. Encyclopaedia Britannica. 〈https://www.britannica.com/topic/Hermetism>, 5.8.2018. 
Dušan R. Živković

\section{THE INFLUENCE OF HERMETICISM ON THE ENCYCLOPEDIC PARADIGM OF DICTIONARY OF THE KHAZARS}

(Summary)

The paper analyzes the impact of Hermeticism on Milorad Pavić's encyclopedic paradigm of Dictionary of the Khazars, through the following aspects: a) autopoiesis; b) the principles of creating and networking of the entries; c) semantic characteristics, realized in polyphony, diffusivity, synchronicity and ambiguities.

Pavićs encyclopedic paradigm revives the cult of Hermes Trismegistos, invoking his divine origin of inventor of writing, encyclopedic systems as well as the transmitter of information - the embodiment of the principles of inter-contextuality. Also, Pavic upgraded hermetic principles, in the creation of hypertext - an interactive system of multiplication of meanings, in multilayered dialogues with readers as collaborators in the structuring of a postmodern hermetic labyrinth.

In hermetic teachings, number 3 is the number of androgyny, and in the theosophical application of hermeticism, there is an idea of pervading religions that had a key influence on the conception of the trinity in unity: the „Red" "Green” and "Yellow” books (Christian, Islamic and Jewish sources) ), as well as in the mission of unifying male and female editions - in assembling Adam's androgynous body on earth and bringing together all spatio-temporal perspectives into a universal time of Dictionary of the Khazars. 